\title{
PARODI DESAIN KAOS KAMENGSKI SEBAGAI GAYA HIDUP
}

\author{
Marsha Audra Hernandya \\ Pascasarjana Pengkajian Seni Rupa Desain Komunikasi Visua lnstitut Seni Yogyakarta \\ E-mail: marshaudra@gmail.com
}

\begin{tabular}{|c|c|}
\hline ARTICLE INFO & ABSTRAK \\
\hline $\begin{array}{l}\text { Article history: } \\
\text { Received: } 2 \text { Mei } 2020 \\
\text { Revised: } 11 \text { Mei } 2020 \\
\text { Accepted: } 13 \text { Mei } 2020\end{array}$ & $\begin{array}{l}\text { T-shirts have become a timeless type of clothing. Over the years, } t \text { - } \\
\text { shirts have experienced development which is evidenced by the } \\
\text { changing of its form, design, and also function. Moreover, the } \\
\text { significant increase in consumption level has been accompanied by }\end{array}$ \\
\hline $\begin{array}{l}\text { Keywords: } \\
\text { Design } \\
\text { Parody } \\
\text { Life Style }\end{array}$ & $\begin{array}{l}\text { the growth in the needs of t-shirt production. With these increased } \\
\text { needs, the t-shirt industry is becoming a competitive business for the } \\
\text { manufacturers to produce a wide range of types and designs that can } \\
\text { captivate consumers' interests. One of the strategies is by using } \\
\text { parody elements. } \\
\text { One of the uses of parody designs that attracts attention is } \\
\text { Kamengski's work. Besides the success of bringing parody to each of } \\
\text { his design works, Kamengski often received pros and cons. Apart } \\
\text { from being able to identify the market gaps and being creative in the } \\
\text { existing limitations, the use of parody on Kamengski shirts design is } \\
\text { considered as an act of plagiarism and deemed irresponsible. } \\
\text { Beyond all of the pros and cons, the use of parody in t-shirts } \\
\text { designing can not be denied has become a part of the social lifestyle. } \\
\text { This article will discuss the use of parody on t-shirt designs as a } \\
\text { lifestyle, with a case study of Kamengski t-shirts. }\end{array}$ \\
\hline
\end{tabular}

\section{PENDAHULUAN}

Gaya hidup atau sering kita sebut sebagai lifestyle dewasa ini mengalami pertumbuhan dan perkembangan dari tahun ke tahun, gaya hidup juga kerap dikaitkan kepada sifat konsumtif yang ada pada diri manusia. David Chaney, dalam bukunya yang berjudul "Lifestyle" menjelaskan gaya hidup dalam berbagai bentuk, namun masih saling berkaitan. Gaya hidup merupakan bagian dari kehidupan sosial sehari-hari dunia modern. Gaya hidup yang terus tumbuh dan berkembang dapat memengaruhi berbagai bidang lain, seperti bidang ekonomi, pendidikan, politik hingga busana atau dalam Bahasa Inggris disebut fashion.

Berbicara tentang fashion, banyak ragam jenis dan bentuk yang telah ada, namun kaos adalah salah satu jenis fashion yang bisa dikatakan tidak lekang oleh waktu. Keberadaan kaos selalu ada dalam perkembangan dan kemajuan zaman, selain itu kaos dapat di dapatkan lebih 
mudah dengan bahan yang nyaman dan sederhana. Dalam kemajuan zaman yang ada, kaos juga mengalami pertumbuhan serta perkembangan baik dari segi bahan, fungsi dan desain yang mengikuti kebutuhan masyarakat.

Seiring perkembangannya, kaos menurut fungsinya tidak hanya menjadi pelindung tubuh saja, melainkan dijadikan sebagai alat untuk mengkomunikasikan suatu hal yang dituangkan ke dalam teks atau pun gambar yang ada di dalam desain permukaan kaos. Kebutuhan masyarakat yang terus bertambah, akhirnya membuat produsen kaos saling berlomba untuk merebut hati konsumen.

Dari banyaknya desain kaos yang ada, terdapat desain dengan penggunaan unsur parodi terhadap merek-merek terkenal. Parodi yang digunakan kebanyakan memplesetkan logo atau nama dari sebuah merek terkenal, dan desain tersebut banyak dijumpai media sosial Instagram. Salah satu seniman dengan username Instagram Kamengski, berhasil mencuri perhatian masyarakat dengan karyanya, yang akrab menggunakan unsur parodi pada desain kaosnya. Parodi dalam desain kaos yang dijual di oleh Kamengski menjadi perhatian masyarakat dan bahkan banyak diminati terutama generasi muda atau sering disebut dengan generasi millennial.

Dalam sebuah artikel yang dirilis lifestyle.kontan.co.id 31 Maret 2018, Kamengski atau memiliki nama asli Said, mengatakan penggunaan unsur parodi pada desain kaos yang dijualnya adalah bentuk dari ketidakmampuan diri untuk membeli kaos bermerek, sedangkan untuk membeli kaos lokal dianggap memiliki desain yang kurang bagus. Sehingga dengan keterbatasan tersebut, akhirnya Said membuat mereknya sendiri yang diberi nama Kamengski, berdiri pada tahun 2009 dan hingga sekarang memiliki pengikut di Instagram sebanyak 174 ribu.

Fenomena penggunaan parodi pada desain kaos tentunya menjadi hal yang tidak dapat dipungkiri, mengingat semakin banyaknya desain-desain kaos yang mempelesetkan logo, merek bahkan tidak segan untuk menjelek-jelekannya demi memenuhi kebutuhan masyarakat yang semakin meningkat. Tidak jarang, penggunaan parodi pada desain kaos juga dianggap tidak bertanggung jawab dan hanya mengacak budaya yang ada.

Namun meskipun di anggap tidak bertanggung jawab dan hanya mengacak budaya, dari data pendahuluan yang didapat oleh penulis menggunakan googleforms, 23 dari 30 orang menyatakan penggunaan parodi pada desain kaos menentukan keputusan mereka membeli kaos. Kemudian dengan metode yang sama, didapat data pendahuluan 19 dari 30 orang menyatakan bahwa penggunaan parodi dianggap baik dan diperlukan untuk menarik minat mereka, sedangkan 11 orang lainnya beranggapan bahwa menggunakan unsur parodi adalah tindakan plagiat, tidak kreatif dan merusak desain asli. 
Dari fenomena maraknya penggunaan parodi sebagai desain kaos dan data pendahuluan yang didapat, penulis melihat adanya sebuah rumusan masalah yang dapat dikaji oleh penulis yaitu, bagaimana kajian penggunaan parodi pada desain kaos sebagai gaya hidup?

\section{METODE PENELITIAN ATAU PERANCANGAN}

Metode penelitian yang akan digunakan dalam penelitian ini adalah Metode Penelitian Kualitatif. Metode Penelitian Kualitatif menurut Prof Sugiyono (2006:15) adalah metode penelitian yang berlandaskan pada filsafat postpositivme, digunakan untuk meneliti pada kondisi objek yang alamiah, (sebagai lawannya adalah eksperimen) dimana peneliti adalah sebagai instrumen kunci, pengambilan sempel data dilakukan secara purposive dan snowbaal, teknik pengumpulan dengan trianggulasi (gabungan), analisis data bersifat induktif/kualitatif, dan hasil penelitian lebih menekan makna dari pada generalisasi.

Sedangkan pendekatan yang digunakan dalam penelitian ini adalah pendekan studi kasus. Penelitian dengan pendekatan studi kasus adalah pendekatan yang penelitiannya mengeksplorasi kehidupan nyata, sistem terbatas kontemporer (kasus) atau beragam sistem terbatas (berbagai kasus), melalui pengumpulan data yang detail dan mendalam yang melibatkan beragam sumber informasi atau sumber informasi majemuk misalnya pengamatan, wawancara, bahan audiovisual, dokumen, dan berbagai laporan (Cresswell, 2015:135).

Dalam penelitian ini studi kasus yang akan dikaji adalah objek penggunaan parodi terhadap desain kaos Kamengski, serta pengalaman dan persepsi pembeli terhadap kaos berunsurkan parodi. Peneliti mengumpulkan data, mempelajari dokumen-dokumen/arsip, mengamati perilaku, dan mewawancarai para partisipan dengan pertanyaan yang sifatnya terbuka.

\section{Metode Pengumpulan Data}

\section{a. Observasi / Pengamatan}

Dalam penelitian ini penulis melakukan pengumpulan data dengan observasi atau pengamatan melalui media jejaring sosial Instagram, pengamatan ini dilakukan untuk mengetahui objek kajian desain. Objek pengamatan yang dipilih sebagai sampel ada tiga desain kaos karya Kamengski, dengan melakukan pencatatan berupa diskripsi dari objek pengamatan. 


\section{b. Wawancara}

Selain melakukan observasi atau pengamatan, penulis juga melakukan wawancara. Peneliti menggunakan jenis wawancara semi terstruktur, dimana pertanyaannya tidak mengikat dan flexibel bisa berubah-ubah sesuai sengan situasi kondisi pada saat melakukan wawancara.

Peneliti melakukan wawancara bertahap untuk memperoleh data kemudian mereduksi data data yang sesuai dengan permasalahan dan menyajikan dalam bentuk tulisan. Wawancara dilakukan dengan 8 narasumber yang mengetahui penggunaan unsur parodi terhadap kaos Kamengski. Pertanyaan wawancara yang dibuat oleh penulis berisi tentang, bagaimana persepsi desain pada kaos terutama parodi dan pengalaman membeli kaos sebagai bentuk gaya hidup masa kini.

\section{PEMBAHASAN}

\subsection{Tinjauan Pustaka}

Ada pun beberapa tinjauan pustaka penelitian terdahulu yang sudah dilakukan sebelumnya, beberapa tinjauan pustaka yang sudah dilakukan berkaitan tentang persepsi, kaos dan penggunaan parodi pada karya seni. Dalam jurnal "Eksistensi Ilustrasi Kaos Bertema Bali di Kota Denpasar" oleh (Eldiana, Ni Ketut, 2015), membahas tentang eksistensi minat pembeli terhadap ilustrasi kaos bertema Bali di kota Denpasar dan untuk mengetahui apa makna ilustrasi budaya lokal yang terdapat pada elemen visual kaos bertema Bali. Penelitian tersebut menggunakan metode deskriptif kualitatif, sesuai dengan pendekatan kualitatif maka secara spesifikasi analisisnya ditunjang dengan analisis semiotika. Hasilnya, penelitian yang telah diperoleh bahwa minat pembeli terhadap kaos yang paling banyak adalah kaos dengan desain ilustrasi yang bergambar karikatur atau kartun dan ada teks "Bali". Selain itu kaos dengan ilustrasi barong juga banyak dipilih, sehingga desain kaos bertemakan kebudayaan banyak diminati.

Dalam jurnal "Tinjauan Desain Grafis Kaos Sablon Graffiti di gardu House Jakarta" oleh (Fikril dkk, 2009), menjelaskan bagaimana visualisasi, konsep, dan penerapan desain pada kaos sablon graffiti di Gardu House Jakarta. Penelitian ini menggunakan jenis penelitian deskriprif kualitatif dengan teknik wawancara terhadap seniman yang membuat desain kaos, antara lain adalah Bujangan Urban, Koma (Indo), Muth, dan Sidvizeus selaku narasumber. Hasilnya 6 dari 10 desain yang ada menerapkan fungsi identitas, sedangkan sisanya menerapkan fungsi edukasi dan fungsi persuasi. 
Kedua jurnal tersebut sama-sama membahas kaos dengan pendekatan yang sama yaitu deskriptif kualitatif, dan menganalisa objek desain pada kaos yang ada. Desain kaos yang dikaji sama-sama menjadi sebuah alat yang digunakan untuk menyampaikan pesan atau suatu hal terhadap calon pembeli baik itu membawa budaya di tempat asal, atau pun idealis seorang seniman untuk menunjukan identitasnya ke dalam sebuah karya desain kaos untuk dapat dikenali. Meski pun keduanya tidak menggunakan unsur parodi terhadap desain kaos yang dibuat, keduanya sama-sama menunjukan fungsi kaos sebagai alat untuk menyampaikan pesan yang kaya oleh makna.

Hal tersebut tentu sejalan dengan Sumbo Tinarbuko (2006), dalam jurnal "Semiotika Desain Oblong Dagadu Djokdja”, bagaimana produk kaos oblong Dagadu Djokdja dapat mengemas budaya Yogyakarta ke dalam sebuah desain kaos oblong dengan memberikan estetika pada subjek yang sederhana dan menjadi daya tarik bagi pembeli. Perbedaan dengan kedua jurnal sebelumnya, adalah objek kajian kaos oblong Dagadu Djokdja menggunakan idiom parodi ke dalam desain kaosnya. Tidak hanya membahas tentang kekayaan budaya yang ada di Yogyakarta, tetapi juga dibenturkan dengan parodi yang menjadi kunci daya tarik pembeli. Sumbo Tinarbuko (2006) mengatakan bahwa parodi adalah salah satu bentuk representasi. Uniknya, representasi tersebut selalu ditandai dengan sifat pelencengan, penyimpangan, dan plesetan makna, atau jamak disebut dengan representasi palsu.

Penggunaan idiom parodi pada sebuah karya seni sebenarnya bukan hal yang baru, tetapi bagaimana penggunaan parodi dapat diterima ke dalam masyarakat. Dalam jurnal "Pendekatan Parodi, Simbolik dan Metafora pada Karya Seni Jogja Internasional” oleh (Sari Wulandari, 2013), membahas tentang karya patung menyerupai tokoh superhero Spider-Man namun mengenakan blangkon dan sarung, pada Pameran Negari Ngayogyakarta Hadiningrat 2012 yang merupakan sebagian dari Festival Seni Rupa 2012 Negari Ngayogyakarta Hadiningrat. Patung yang menyerupai tokoh superhero Spider-Man tersebut memiliki pesan-pesan yang disampaikan secara simbolik, metaforik dan parodik khas masyarakat Yogyakarta.

Secara keseluruhan, penelitian sebelumnya belum menjelaskan secara detail tentang bagaimana penggunaan idiom parodi pada desain kaos dapat menjadi gaya hidup dan persepsi masyarakat terhadap penggunaan parodi pada desain kaos sendiri. Penelitian-penelitian yang telah ada dapat dilengkapi oleh penelitian ini. Kebaharuan media dalam fenomena kaos Kamengski, dapat memperkaya pengetahuan dengan menjelaskan kajian tentang penggunaan parodi pada desain kaos sebagai gaya hidup. 


\subsection{Deskripsi Data Visualisasi Desain Kaos Kamengski}

Desain pada kaos yang dijual oleh Kamengski sangatlah bervariasi. Hampir semuanya menggunakan idiom parodi baik dalam memplesetkan merek, representasi palsu, dan merekonsruksi ulang desain merek atau pun logo terkenal. Dalam penelitian ini, penulis mengambil tiga sampel dari penggunaan parodi pada desain kaos di Kamengski.

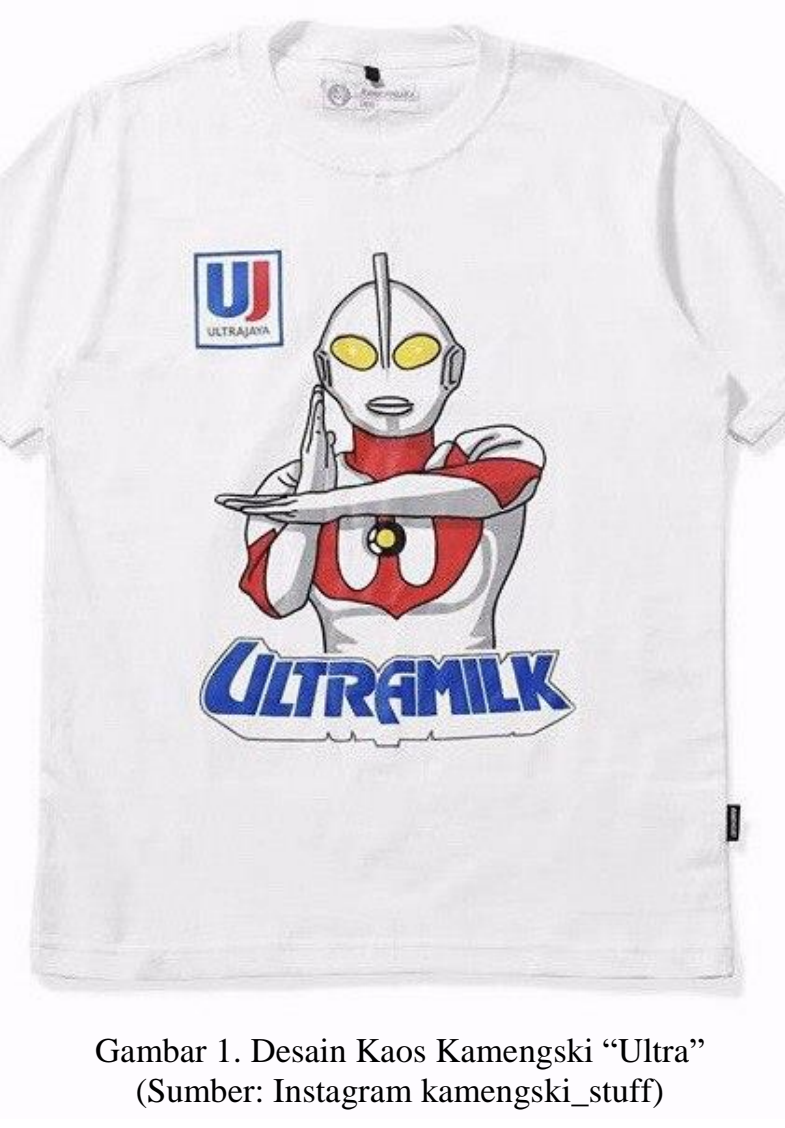

Pada visualisasi desain kaos, gambar 1 adalah kaos yang dibuat oleh Kamengski dan diunggah ke dalam sosial media Instagram "kamengski_stuff" dengan judul "Ultra" pada tanggal 18 Mei 2019. Pada desain kaos gambar 1, terlihat gambar tokoh superhero yang dikenal sebagai Utraman. Tokoh superhero Utraman tersebut digambarkan memiliki mata berwarna kuning, dengan bagian tubuh berwarna putih, abu-abu dan merah di bagian leher, dada dan kedua sikut.

Tepat di bawah gambar tokoh superhero Ultraman, terdapat teks bertuliskan "Utramilk" berwarna biru dengan bayangan putih. Gambar Utraman menggunakan garis hitam tipis, begitu pun pada teks "Ultramilk". Jika diperhatikan, bagian kiri atas terdapat sebuah logo huruf "U" warna biru dan "J" warna merah, dibawahnya terdapat teks "Ultra Jaya" yang dibingkai menggunakan garis persegi berwarna biru. 


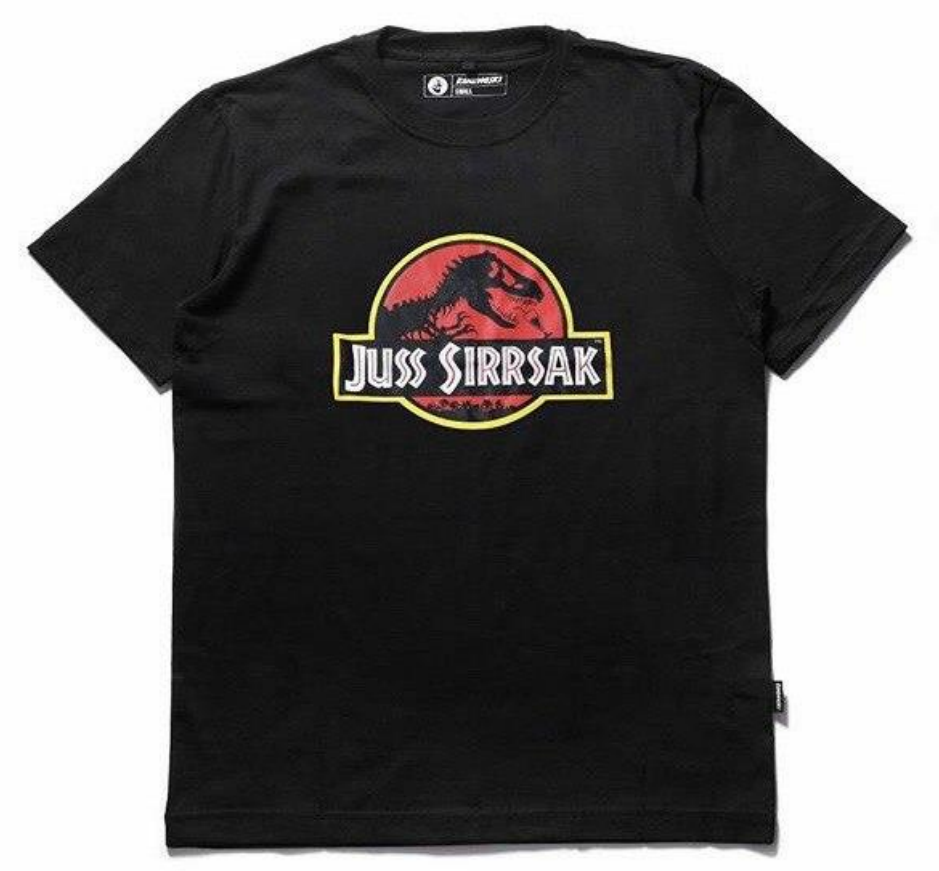

Gambar 2. Desain Kaos Kamengski "Jus sirsak tee"

(Sumber: Instagram kamengski_stuff)

Pada visualisasi desain kaos, gambar 2 adalah kaos yang dibuat oleh Kamengski dan diunggah ke dalam sosial media Instagram "kamengski_stuff” dengan judul "Jus sirsak tees" pada tanggal 8 Juli 2019. Pada desain kaos gambar 2, terlihat gambar siluet menyerupai kerangka dinosaurus berwarna hitam dengan background warna merah sehingga terlihat mencolok. Tepat di bawah gambar siluet menyerupai kerangka dinosaurus, terdapat teks "JUSS SIRRSAK" dengan warna putih dan latar berwarna hitam.

Terdapat garis luar warna kuning yang terlihat mencolok dengan warna kaos yang berwarna hitam, garis luar warna kuning tersebut mengelilingi gambar siluet dinosaurus dan teks yang ada. Jika diperhatikan, terdapat siluet menyerupai gelas yang berada dekat dengan mulut siluet dinosaurus. Siluet yang menyerupai gelas tersebut memiliki bentuk seperti gelas minuman dingin, dimana terdapat pegangan panjang di bawah gelas, hal tersebut didukung dengan adanya siluet berbentuk sedotan di siluet gelas tersebut. 


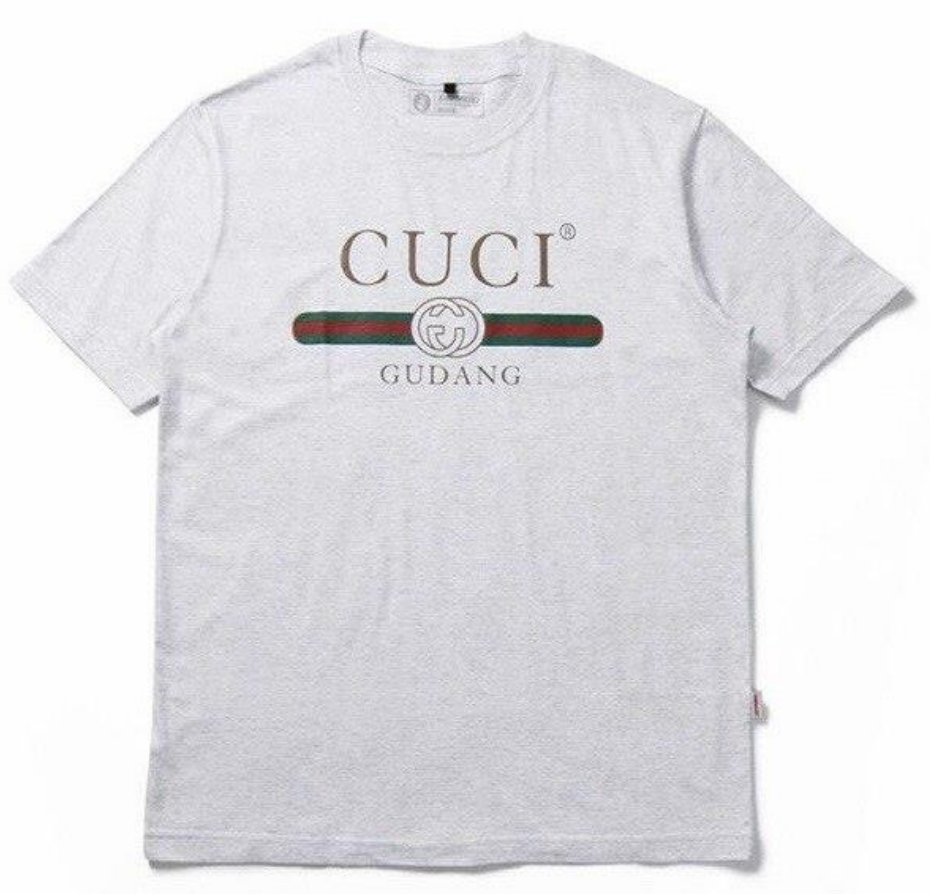

Gambar 3. Desain Kaos Kamengski "Cucci misty white" (Sumber: Instagram kamengski_stuff)

Pada visualisasi desain kaos, gambar 3 adalah kaos yang dibuat oleh Kamengski dan diunggah ke dalam sosial media Instagram "kamengski_stuff” dengan judul "Cucci misty white" pada tanggal 14 Juli 2019. Pada desain kaos gambar 3, terlihat teks "CUCI" yang cukup terlihat dengan warna coklat keemasan. Kemudian dibagian bawahnya terdapat tiga garis berwarna hijau dan merah ditengah, dibagiannya tengah garis tersebut terdapat gambar menyerupai kepala sabuk yang bewarna putih dengan garis luar coklat keemasan sama dengan warna yang digunakan pada teks "CUCI".

Dibawah garis tersebut terdapat teks "GUDANG", dengan warna coklat keemasan. Teks "GUDANG" tersebut memiliki ukuran yang relatif kecil daripada teks yang pertama, sehingga pada saat melihat keseluruhan desain teks "GUDANG" tersebut dilihat paling akhir.

\subsection{Analisis Desain Parodi Kamengski}

Desain yang dibuat pada gambar 1 dan gambar 2 menggunakan gambar illustrasi. Bentuk ilustrasi dalam desain grafis tidak selalu berupa gambar, namun bisa berupa foto, goresan, garis, warna, tekstur, huruf, dan sembarang elemen visual yang dapat mendukung tujuan komunikasi 
dan estetika. Dalam desain grafis, terdapat beberapa teknik pembuatan ilustrasi, yaitu sablon, cetak digital, dan komputer grafis (supriyono, $2010: 170$ ).

Desain ilustrasi sebagian besar mengandung idiom parodi yang berisi sindiran maupun kritikan dengan cara mengolok-olok sebuah bentuk atau peristiwa di masa lalu dengan bahasa gambar yang lebih lucu. Keberadaan idiom parodi pada ilustrasi kaos Kamengski dapat dilihat dari upaya untuk mengubah (dekonstruksi) bentuk asli dengan melebih-lebihkannya melalui distorsi bentuk dan teks.

Piliang (2012: 183) mendefinisikan parodi sebagai sebuah komposisi dalam prosa atau puisi yang didalamnya kecenderungan- kecenderungan pemikiran dan ungkapan karakteristik dalam diri seseorang pengarang atau kelompok pengarang imitasi sedemikian rupa untuk membuatnya tampak absurd, khususnya dengan melibatkan subjek-subjek lucu dan janggal, imitasi dari sebuah karya yang dibuat modelnya kurang lebih mendekati aslinya, akan tetapi disimpangkan arahnya, sehingga menghasilkan efek-efek kelucuan.

Bila diamati, telah terjadi pembongkaran struktur-struktur yang akhirnya menciptakan bentuk baru baik pada gambar 1, gambar 2 dan gambar 3. Pada desain ilustrasi gambar 1, telah mengalami dekonstruksi bentuk Ultramilk yang seharusnya adalah bentuk susu UHT, menjadi tokoh superhero Ultraman. Keunikan pada desain ini adalah kedua objek desain tersebut samasama menggunakan kata "ULTRA" meski pun dengan memiliki akhiran dan makna yang berbeda. Jika melihat desain gambar tersebut Kamengski tidak mengubah bentuk asli tokoh superhero Ultraman dan tidak mengubah teks yang ternyata adalah merek susu Ultramilk, yang dilakukan oleh Kamengski adalah menggabungkan kedua objek yang berbeda ke dalam satu kesatuan desain dengan memiliki kesamaan kata "ULTRA".

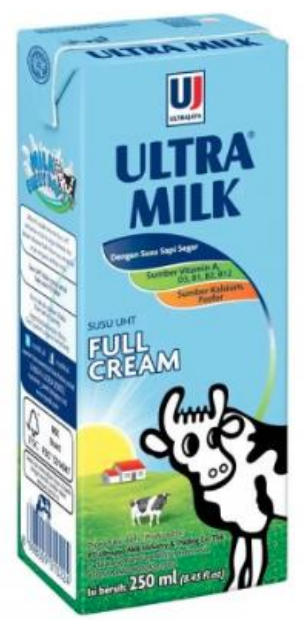

Gambar 4. Susu Ultramilk (Sumber: https://www.blanja.com) 


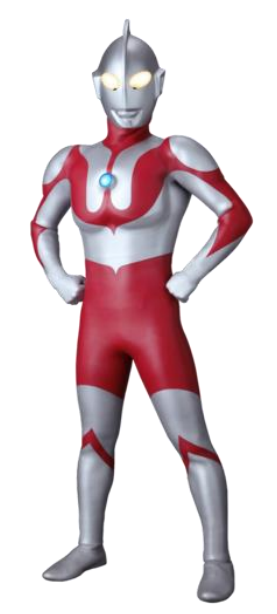

Gambar 5. Ultraman (Sumber: https://ultra.fandom.com)

Pada desain ilustrasi gambar 2, kesatuan desain tersebut adalah bentuk dekonstruksi dari logo flim terkenal Jurassic Park. Penggunaan warna background dan garis luar pada desain Kamengski mengalami perubahan, pada logo asli Jurassic Park warna background berwarna kuning sedangkan Kamengksi menggunakan warna merah. Kemudian untuk garis luar logo asli Jurassic Park menggunakan warna merah, sedangkan Kamengski mengubahnya ke warna kuning.

Tata letak siluet tidak diubah oleh Kamengski, yang mengalami pengubahan adalah teks yang seharusnya bertuliskan "JURASSIC PARK" menjadi "JUS SIRRSAK". Pengubahan teks tersebut tentunya mengubah makna yang terkandung di dalam teks, dari yang seharusnya mengidentitaskan sebuah flim menjadi kalimat jus sirsak minuman. Ditambah dengan penambahan siluet gelas yang menandakan gelas tersebut untuk meminum minuman yang dingin, kerena bentuk gagang gelas yang panjang dan juga adanya sedotan di gelas tersebut.

Jika dilihat secara keseluruhan seakan-akan dinosaurus yang ada dalam gambar bukanlah dinosaurus yang menunjukan flim Jurassic Park, melainkan dinosaurus yang sedang meminum jus sirsak karena didukung dengan teks "JUS SIRRSAK". Pada desain gambar 2 dapat menciptakan sebuah lelucon humor yang membangkitkan perasaan menggelikan. Lelucon humor kini banyak diciptakan dalam masyarakat sebagai sarana untuk mencapai suatu tujuan atau menyampaikan suatu maksud (Parmono, 2008: 42). Kategori humor yang terdapat pada gambar 2 diciptakan melalui ketaksesuaian bentuk dan penambahan kalimat yang mendukung dekonstruksi pada desain yang dibuat. 


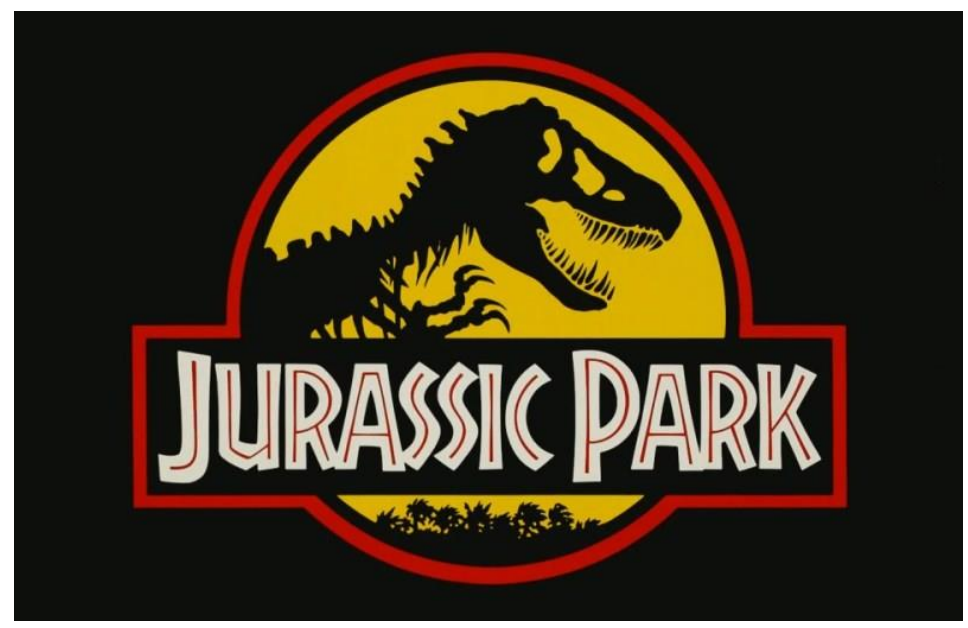

Gambar 6. Logo Jurasisic Park (Sumber: https://www.grapheine.com)

Pada gambar 3, penggunaan parodi desain Kamengski berada pada pengubahan merek terkenal GUCCI. Dalam desain tersebut Kamengski melakukan dekonstruksi baik terhadap bentuk dan teks yang mengubah makna dari arti yang sebenarnya. Merek "GUCCI" memiliki logo yang terkenal dan mudah dipahami hanya dengan melihat huruf "C" dan "G", atau hanya dengan melihat tiga garis berwarna hijau dan merah ditengah. Namun dalam desain Kamengski, “GUCCI” mengalami dekonstruksi yang menjadi "CUCI". Meskipun dalam pengucapan kata "GUCCI" dan "CUCI" hampir sama, tetapi memiliki makna yang berbeda, "GUCCI" adalah merek busana yang terkenal sedangkan "CUCI" memiliki makna mencuci yaitu membersihkan.

Ditambah teks "GUDANG" yang berada di bawah logo, sehingga jika desain dilihat secara keseluruhan akan ada kalimat "CUCI GUDANG". Kalimat tersebut adalah bentuk dekonstruksi yang dilakukan Kamengski terhadap logo merek terkenal menjadi sebuah parodi, sama dengan desain gambar 2, parodi desain pada gambar 3 diciptakan melalui perubahan kalimat yang mendukung dekonstruksi pada desain yang dibuat.

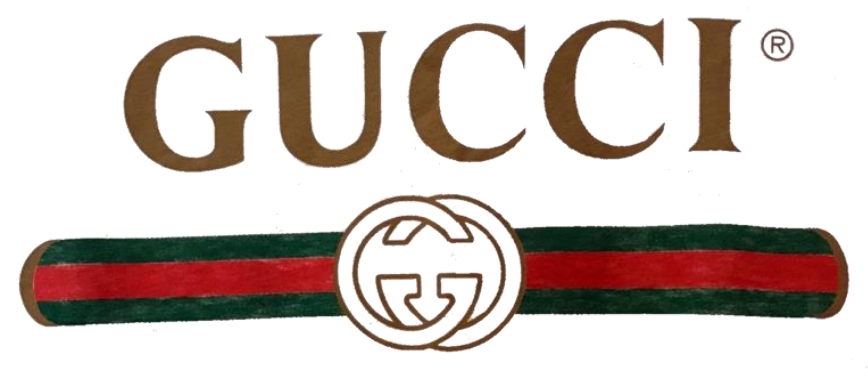




\section{Gambar 7. Logo GUCCI}

(Sumber: google)

\subsection{Hasil Pembahasan}

Dalam penelitian ini peneliti juga mendapatkan data wawancara dari 8 orang narasumber tentang desain kaos milik Kamengski, informasi berupa data-data yang beragam baik dari persepsi, preferensi, pengalaman motivasi telah mendapatkan hasil yaitu tiga tipe pembeli yang diuraikan ke dalam tabel sebagai berikut :

\begin{tabular}{|c|c|c|c|}
\hline \multirow[b]{2}{*}{$\begin{array}{c}\text { Pertanyaan } \\
\text { Terkait }\end{array}$} & \multicolumn{3}{|c|}{ Tipe Pembeli } \\
\hline & Tipe A & Tipe B & Tipe $\mathrm{C}$ \\
\hline Persepsi & $\begin{array}{l}\text { Memplesetkan logo atau pun } \\
\text { merek pada desain kaos } \\
\text { Kamengski adalah hal yang } \\
\text { kreatif dan unik }\end{array}$ & $\begin{array}{l}\text { Memplesetkan logo pada } \\
\text { desain kaos Kamengski boleh } \\
\text { dilakukan dengan mengetahui } \\
\text { tujuannya, jika tidak mampu } \\
\text { membeli yang original, } \\
\text { membeli kaos dengan } \\
\text { plesetan logo tidak apa-apa }\end{array}$ & $\begin{array}{l}\text { Memplesetkan logo atau } \\
\text { pun merek pada desain } \\
\text { kaos Kamengski adalah } \\
\text { hal yang tidak begitu baik } \\
\text { karena merugikan pihak } \\
\text { lainnya (yang } \\
\text { diparodikan) }\end{array}$ \\
\hline $\begin{array}{l}\text { Preferensi } \\
\text { Desain }\end{array}$ & $\begin{array}{l}\text { Desain Kamengski selalu } \\
\text { menawarkan hal-hal yang } \\
\text { baru dan tidak terduga. Dari } \\
\text { menggunakan merek dan } \\
\text { produk yang mendunia } \\
\text { hingga sederhana selalu } \\
\text { menarik perhatian }\end{array}$ & $\begin{array}{l}\text { Desain dari Kamengski bagus } \\
\text { karena memadupadankan } \\
\text { merek satu dengan lainnya }\end{array}$ & $\begin{array}{l}\text { Desain dengan } \\
\text { menggunakan logo-logo } \\
\text { terkenal dan } \\
\text { menggantinya dengan } \\
\text { tulisan yang lain }\end{array}$ \\
\hline $\begin{array}{c}\text { Jenis } \\
\text { Parodi / } \\
\text { Plesetan }\end{array}$ & 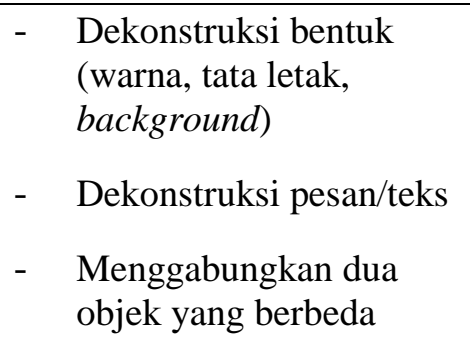 & $\begin{array}{l}\text { - } \begin{array}{l}\text { Menggabungkan dua } \\
\text { objek yang berbeda }\end{array} \\
\text { - } \begin{array}{l}\text { Dekonstruksi bentuk } \\
\text { (warna, tata letak, } \\
\text { background) }\end{array}\end{array}$ & $\begin{array}{ll} & \begin{array}{l}\text { Dekonstruksi } \\
\text { pesan/teks }\end{array}\end{array}$ \\
\hline $\begin{array}{l}\text { Motivasi / } \\
\text { Faktor } \\
\text { Pendorong }\end{array}$ & 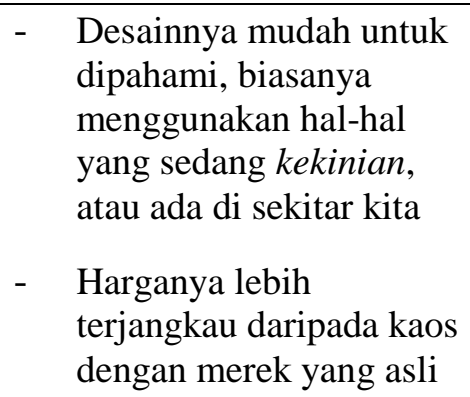 & 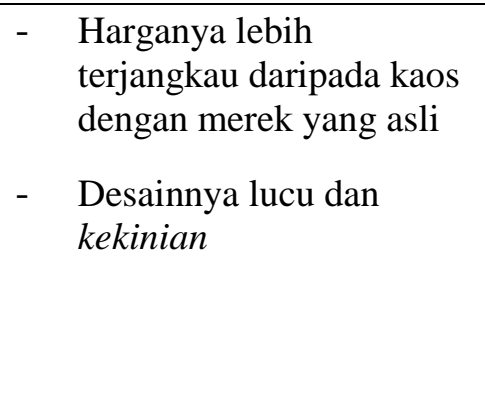 & 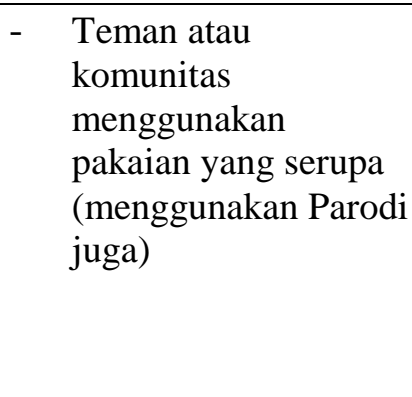 \\
\hline
\end{tabular}


Tabel 1: Hasil Kesimpulan Wawancara

(Sumber: Penulis)

Dari hasil analisis karya desain kaos Kamengski dan hasil wawancara yang telah dilakukan terhadap 8 narasumber, telah menghasilkan tiga tipe konsumen dengan persepsi, preferensi desain, jenis parodi dan motivasi atau faktor pendorong pembeli terhadap desain kaos Kamengski yang diuraikan sebagai berikut :

\section{c. Persepsi}

Perserpsi narasumber terhadap karya Kamengski berbeda-beda dan digolongkan menjadi tiga persepsi, yang pertama adalah yang mendukung penuh penggunaan parodi ke dalam pembuatan desain karena penggunaan parodi dapat menarik minat mereka. Persepsi yang kedua adalah yang mendukung penggunaan parodi dengan tujuan tertentu, seperti faktor ekonomi dan lingkungan serta gaya hidup. Persepsi yang ke tiga memandang penggunaan parodi tidak semestinya dilakukan karena dapat merugikan pihak lainnya (yang diparodikan).

\section{d. Preferensi Desain}

Preferensi desain narasumber dibedakan menjadi tiga jenis, yaitu yang mengetahui dari merek logo yang terkenal dan dekat dengan mereka, kedua desain yang memadupadankan kedua merek menjadi satu, dan yang terakhir penggantian teks/tulisan terhadap sebuah logo.

\section{e. Jenis Parodi / Plesetan}

Preferensi desain narasumber dibedakan menjadi tiga jenis, yaitu dekonstruksi bentuk (warna, tata letak, background), dekonstruksi pesan/teks, dan menggabungkan dua objek yang berbeda menjadi satu.

\section{f. Motivasi / Faktor Pendorong}

Motivasi/faktor dorongan narasumber dibedakan menjadi tiga jenis, yaitu desainnya yang mengikuti perkembangan zaman dan relate dengan kehidupan mereka, kedua faktor ekonomi karena lebih murah, dan yang terakhir adalah telah menjadi gaya hidup.

\section{KESIMPULAN}

Dari pembahasan di atas, dapat disimpulkan bahwa penggunaan parodi desain kaos Kamengski memiliki desain yang selalu dekat dengan masyarakat. Kamengski membuat desain yang sederhana dengan memasukan hal-hal yang dekat di sekitarnya, seperti desain kaos Ultramilk yang dipadupadankan dengan Ultraman. Tidak hanya sekadar merusak hal sudah ada, tetapi Kamengski juga menjadi seniman yang cerdas dan kritis dalam pengambilan ide kreatif yang dituangkan ke dalam karya desainnya. Meskipun penggunaan desain parodi pada kaos 
Kamengski dianggap salah oleh sebagian narasumber dan merugikan pihak lainnya, kaos desain karya Kamengski ini tetap dicari oleh masyarkat terutama di Indonesia.

\section{DAFTAR PUSTAKA}

David Chaney., 2011. LIFE STYLE sebuah pengantar komprehensif. Yogyakarta : Jalasutra.

John W, Creswell., 2015. Penelitian Kualitatif dan Desain Riset. Edisi Ke-3. Yogyakarta: Pustaka Pelajar.

Parmono, Kartini., 2008. Horizon Estetika. Yogyakarta: Penerbit Lima.

Pialang, Yasraf Amir., 2003. Hipersemiotika Tasfir Cultural Studies Atas Matinya Makna. Bandung: Jlasutra.

Pujiriyanto., 2005. Desain Grafis Komputer (Teori Grafis Komputer). Yogyakarta: C.V. ANDI OFFSET.

Prof. Dr. Sugiyono. 2006., Metode Penelitian Pendidikan (Pedekatan Kuantitatif, Kualitatif, dan $R \& D)$. Bandung : Alfabeta.

Supriyono, Rakhmat., 2010. Desain Komunikasi Visual - Teori dan Aplikasi. Yogyakarta: Andi.

$\underline{\text { Artikel jurnal: }}$

Eldiana Tri Narulita, Ni Ketut Pande Sarjani., 2015. Eksistensi Ilustrasi Kaos Bertema Bali Di Kota Denpasar. Jurnal "SEGARA WIDYA”, Vol.3, No.1, ISSN: 2354-7154.

Sari Wulandari., 2013. Pendekatan Parodi, Simbolik Dan Metafora Pada Karya Seni Jogja Internasional. Jurnal HUMANIORA Vol.4, No.1, Hal: 465-474.

Sumbo Tinarbuko., 2006. Semiotika Desain Oblong Dagadu Djokdja. Junal Ilmu Komunikasi, Vol. 3, No. 1, Hal: 79-94.

N Fikril Arifin., 2014., Tinjauan Desain Grafis Kaos Sablon Graffiti Di Gardu House Jakarta. Jurnal Pendidikan Seni Rupa, Vol. 2, No.2, Hal: 19-28.

Website:

Blanja, 2020. URL: https://www.blanja.com/katalog/p/fnb/ultra-milk-putih-250-ml 25088401.

Diakses pada 24 April 2020

Clipartmax, 2020. https://www.grapheine.com/en/actulogo-en/the-story-of-the-big-bad-jurassicpark-logosaurus. Diakses pada 24 April 2020 
Grahein, 2020. https://www.grapheine.com/en/actulogo-en/the-story-of-the-big-bad-jurassicpark-logosaurus. Diakses pada 24 April 2020

Kontan News, Data Financial, 2020. URL: https://lifestyle.kontan.co.id/news/bergaya-denganmengacak-budaya. Diakses pada 22 April 2020.

Ultraman Wiki, 2020. URL: https://ultra.fandom.com/wiki/Ultraman_80_(character). Diakses pada 24 April 2020. 